Warsonofiusz Doroszkiewicz

Uniwersytet w Białymstoku

warsonofiusz@gmail.com
Data przesłania tekstu do redakcji: 18.09.2014

Data przyjęcia tekstu do druku: 25.09.2014

\title{
Geneza i ewolucja relacji państwo - Kościół w Bizancjum
}

Aвstract: Doroszkiewicz Warsonofiusz, Geneza i ewolucja relacji państwo-Kościół w Bizancjum (Genesis and Evolution of Relation State - Church in Byzantine Empire). "Poznańskie Studia Slawistyczne" 10. Poznań 2016. Publishing House of the Poznań Society for the Advancement of the Arts and Sciences, pp. 17-24. ISSN 2084-3011.

Practicaly until today there haven't appeared objectiv scientific works concerning begining and evolution of the byzantine monarchy. Christian Church after 300 years of awful persecutions came out of the underground and had to find itself in the new reality, had to decide whether reconcile and cooperate with the society, or isolate from the fallen world, as had done sects, and save chosen. Church chose the first option and took responsibility for the salvation of the world. In reality the emperor, the recent persecutor of the Church, must have persuaded christians, that he himself was not only their friend but good-doer also. Therefore in the $4^{\text {th }}$ century beside the Church of the eschatological character appeared a new power of a temporary character. History of the Eastern Roman Empire is also the history of the relationship between Church and the empire focused on the earthly dimension of its mission. The very symbol of this relationship was famous byzantine eagle as a representation of one body and two different ideological trends. However those relations had not always been ideal, more or less those two bodies existed through the period of 1100 years on the principle of symphonia-agreement. After the fall of the Eastern Roman Empire, Church by the will of God survived in order to continue its mission of salvation of the fallen world.

Keywords: God; Church; Eastern Roman Empire; Byzantium; emperor; salvation

Polityka religijna Konstantyna Wielkiego zakładała zrównanie praw wszystkich wyznań na terenie Cesarstwa Rzymskiego (Ostrogorski 1929: 37), czego świadectwem był edykt mediolański (313). Już na początku IV wieku chrześcijaństwo - po trzech wiekach okrutnych prześladowań - stało się najbardziej dynamiczną i najlepiej zorganizowaną religią Imperium Rzymskiego. Następcy Konstantyna, nadając chrześcijaństwu coraz większe prerogatywy, systematycznie ograniczali przywileje tradycyjnych religii politeistycznych, których prawo do nienaruszalności było zagwarantowane w edykcie mediolańskim. Wyjątkiem był casus związany 
z panowaniem Juliana Apostaty (361-363), który zapragnął w dość krótkim czasie zmienić bieg historii i przywrócić wierzeniom pogańskim te same priorytety, które przyświecały niegdyś epoce przedkonstantyńskiej. Rozumiał on jednak doskonale, że jakiekolwiek rozwiązania siłowe w stosunku do chrześcijaństwa nie mogły być brane pod uwagę, ponieważ ten scenariusz w niedawnej przeszłości nie tylko nie zagroził tej wspólnocie, ale jeszcze wzmocnił ją, doprowadzając do zwycięstwa. Jedynym sposobem na osłabienie Kościoła było wprowadzenie planu kompromitacji jego instytucji oraz wyznawców Chrystusa. Gdyby nie tragiczny, śmiertelny wypadek na polu bitwy, być może cesarz w jakiejś mierze osiągnąłby swój cel. Po śmierci Apostaty na nowo rozgorzała w kręgach kościelno-politycznych dyskusja na temat relacji państwa i Kościoła w Cesarstwie Wschodniorzymskim. Należy pamiętać o tym, że podczas ery konstantyńskiej Kościół nie tworzył swojej własnej teorii politycznej, jak to robił Kościół zachodni pod panowaniem Karola Wielkiego (Doroszkiewicz 2012: 283-290), lecz zaadaptował odziedziczoną po czasach apostolskich teorię rzymską i włączył ją w chrześcijańską koncepcję Boga, świata i człowieka. Rzymska teoria sięgała swymi korzeniami politycznych poglądów stoików, a jej twórcą był Zenon z Kition (335-262). Uznawał on za cnotę najwyższe $\mathrm{i}$ jedyne dobro, pojmowane jako życie zgodne $\mathrm{z}$ zasadami rozumu rządzącego światem. Co się zaś tyczy filozofii politycznej, głosił, że możliwe jest funkcjonowanie jednego cesarstwa, w którym obywatele żyliby według stoickich ideałów, a rządziłby nimi mądry i sprawiedliwy cesarz, który przestrzegałby wszelkich zasad filantropii i wzorował się na niebiańskim rozumie rządzącym światem, czyli tym, który stoi na czele bogów. Ta więc koncepcja ziemskiego cesarstwa opierałaby się na idei, że ziemski władca, czyli cesarz, będąc wybrańcem rządzącego wszechświatem najważniejszego Boga, od niego otrzymywałby przywileje. W ten sposób powstała stoicka idea boskiego kultu cesarza, która już w drugim wieku przed Chrystusem została z powodzeniem zaadaptowana w politycznych kręgach rzymskich, znajdując jednocześnie odzwierciedlenie w twórczości Cycerona (106-43) i Seneki (4-45) (Mazzarino 1966: 42).

Wraz z pojawieniem się neoplatonizmu nastąpił powolny regres filozofii stoickiej. Neoplatonizm (II wiek n.e.) zasymilował częściowo filozoficzno-polityczne założenia platońskie, arystotelesowskie, pitagorejskie i stoickie. Jednak przełomu w dziedzinie myśli filozoficzno-politycznej 
dokonał Dion Chryzostom, który łącząc w sposób eklektyczny poglądy stoicko-neoplatońskie i opierając się na politycznej teorii sięgającej czasów starożytnego, greckiego systemu ustrojowego, modelu miasto-państwo, stworzył swoją własną teorię polityczną. System polityczno-ustrojowy miasto-państwo przeszedł drogę ewolucji, a w czasach imperialnych podbojów Aleksandra Macedońskiego zmienił zupełnie strukturę i charakter. Stracił swą aktualność, ponieważ powstała nowa rzeczywistość, imperium obejmujące podbite przez Aleksandra Macedońskiego państwa. Imperium to musiało rządzić się nowymi prawami. Zaistniała potrzeba centralizacji władzy, skupionej w rękach jednego monarchy, czyli uniwersalnego autokraty. W swoim dziele $\Pi \varepsilon \rho \imath \tau \eta \varsigma$ B $\alpha \sigma \imath \lambda \varepsilon \imath \alpha \varsigma$ Dion wyłożył zasady, na których powinna opierać się uniwersalna autokracja ( $\Theta 1 \delta \alpha \varsigma$ 1997: 223). Według niego, idealny ustrój miałby polegać na tym, że idealny monarcha przewodzi mądrym, rozsądnym i roztropnym obywatelom. Uważał, że to realne, bo każdy człowiek - podlegający przecież prawu naturalnemu - nosi w sobie ideę Boga jako uniwersalnego niebiańskiego monarchy albo rozumu. Prawo naturalne zaś nie jest partykularnym prawem konkretnego państwa ani też zbiorem przepisów, spisanym przez ludzi, lecz przejawem wiecznego, transcendentnego i uniwersalnego rozumu. Przedstawicielem tego rozumu na ziemi miałby być monarcha, $\mathrm{z}$ jego nieograniczonymi kompetencjami, jako czynnik jednoczący i gwarant ładu, porządku w cesarstwie (Mazzarino 1966: 43). Prawdopodobnie do politycznej teorii Diona nawiązał św. apostoł Paweł w Liście do Rzymian, pisząc w następujący sposób:

Każdy człowiek niech się poddaje władzom zwierzchnim; bo nie ma władzy, jak tylko od Boga, a te, które są od Boga, przez Boga są ustanowione. Przeto, kto się przeciwstawia władzy, przeciwstawia się Bożemu postanowieniu; a ci, którzy się przeciwstawiają, sami na siebie potępienie ściągają. Chcesz się nie bać władzy? Czyń dobrze, a będziesz miał od niej pochwałę. Jest ona bowiem na służbie u Boga ku dobremu. Ale jeśli czynisz źle, bój się, bo nie na próżno miecz nosi, wszak jest sługą Boga, który odpłaca w gniewie, co źle czyni. Przeto trzeba jej się poddawać, nie tylko w obawie przed gniewem, lecz także ze względu na sumienie... Oddawajcie każdemu, co mu się należy; komu podatek, podatek; komu cło, cło; komu bojaźń, bojaźń, komu cześć, cześć (Rz 13,1-6).

W podobnym duchu wyrażał swe aklamacje pod adresem cesarza Konstantyna Wielkiego Euzebiusz z Cezarei. To prawdopodobnie poglądy Diona Chryzostoma posłużyły mu do wypracowania politycznej teorii ery konstantyńskiej, ale już w kontekście chrześcijańskim (Schwartz 
1913: 51). Będąc przekonany o boskiej misji cesarza Konstantyna, Euzebiusz pisał:

Moje bowiem ramię wybrał Bóg jako narzędzie sposobne do przeprowadzenia swych zamysłów; od morza Brytanii i od owych części ziemi, gdzie słońce według danych sobie praw zachodzić musi, zgoniłem i rozproszyłem mocą wyższą rzeczy straszne, które ogarnęły wszystko, ażeby przeze mnie pouczoną ludzkość przywieść z powrotem do pełnienia jego religii, ażeby również rozszerzyć więcej jeszcze, pod Boga potężnym kierunkiem, zbawienie dającą wiarę (Bober 1965: 112).

Mimo że na początku IV wieku większa część chrystianizującego się imperium oddawała jeszcze boską cześć Konstantynowi, obdarzając go tytułem Pontifex Maksimus, chrześcijańska mniejszość radykalnie odrzucała tę ideę, ale powołując się na autorytet apostoła Pawła, szanowała świętość jego urzędu. Jeszcze w czasach prześladowań chrześcijanie radykalnie odróżniali osobę cesarza od jego funkcji, odmawiając mu boskiej czci, natomiast z estymą odnosząc się do sprawowanego przezeń urzędu. Modlili się do Boga za pomyślność cesarza, a nie do cesarza jako obiektu kultu (Doroszkiewicz 2012: 31). Jedynym podmiotem kultu chrześcijańskiego był Pan, którego Królestwo nie pochodziło z tego świata (J 15,19). To właśnie Królestwo Boga, a nie cesarza rzymskiego, zostało obwieszczone i zainaugurowane przez Chrystusa i w Chrystusie. Dzięki Niemu Ono pojawiło się tutaj i teraz, bo Bóg właśnie Jego uczynił Panem całego stworzenia (Kol 1,23). Jeśli więc Kościół przeciwstawiał się rzymskiemu cesarzowi, to nie z przyczyn socjalno-politycznych ani też z powodu jakiejś szczególnej doktryny politycznej; odrzucał jedynie demoniczne nadużycie pojęcia państwa przez księcia tego świata i odmowę uznania przez pogańskie cesarstwo prawdziwego Pana, od wieków oczekiwanego Mesjasza (Schmemann 1979: 35).

Nawrócenie się Konstantyna na chrześcijaństwo i jego akceptacja Kościoła nie oznaczała zmian ani w wierze, ani w eschatologicznych oczekiwaniach Kościoła. Ksiądz Aleksander Schmemann zauważa, że „siła Krzyża, będąca fundamentalną bronią Kościoła przeciwko demonom, uwolniła imperium od mocy księcia tego świata. Zniszczenie bałwanów uczyniło imperium otwartym na Królestwo Boże, zaś cesarz stał się Jego sługą i orędownikiem" (Schmemann 1979: 36). Aby umożliwić chrześcijanom swobodną partycypację w niedzielnej liturgii i poświęcenie 
się modlitwie, cesarz Konstantyn pierwszym dniem tygodnia wolnym od wszelkiej pracy ogłosił „dzień słońca” albo też „dzień Pana”, jak również skrócił procedury uwalniania niewolników oraz zainicjował współpracę z Kościołem w dziele niesienia pomocy chorym i ubogim (Schmemann 1979: 36). Cesarz był nie tylko najwyższym dowódcą wojskowym, sędzią, prawodawcą, ale też obrońcą Kościoła i wiary, wybrańcem Boga, żywym symbolem chrześcijańskiego cesarstwa, dlatego też Kościół nadał mu tytuł równiego apostołom (Doroszkiewicz 2012: 29-31).

Nie należy zapominać o tym, że w Kościele istniała również tradycja hieratyczna, oparta na założycielu Kościoła Jezusie Chrystusie. Tradycja ta rozwinęła się jeszcze za życia apostołów i sformułowała swoje eklezjalne struktury przed nawróceniem się cesarza Konstantyna na chrześcijaństwo. W okresie tzw. przełomu konstantyńskiego tradycja ta została użyta do przewartościowań w związku z nowymi warunkami funkcjonowania Kościoła, to znaczy do określenia jego miejsca i roli. Trzeba pamiętać, że obie rzeczywistości miały to samo źródło, ale zupełnie inne cele. „Inne są cele cesarstwa, zaś inne Kościoła, Pan ustanawia królestwa i je znosi i nie ma wyższej

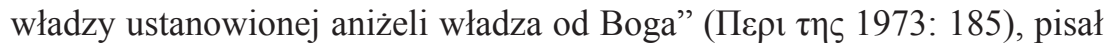
w IV wieku św. Bazyli Wielki, św. Grzegorz Teolog zaś w nieco łagodniejszym tonie dodawał, że „Cesarze powinni z Chrystusem współrządzić i z

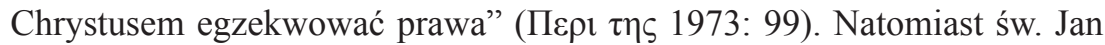
Chryzostom, który praktycznie przez cały okres swej biskupiej posługi był skonfliktowany z władzą świecką, pisał, że „zadaniem cesarzy jest rządzić i być rządzonymi przez Boga, gdyż wszystko jest dziełem Bożej mądrości”

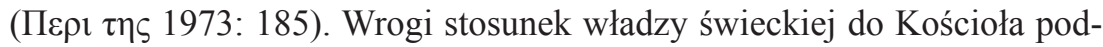
czas trzystu lat prześladowań nazwany był „wielkim nieporozumieniem” (Schwartz 1913: 66), a w epoce konstantyńskiej rozpoczął się pozytywny proces normalizacji stosunków pomiędzy państwem i Kościołem. Władza świecka zaczęła aprobatywnie określać się nie tylko w stosunku do prawa Bożego, ale również do władzy kościelnej. Justyniańska teoria tzw. symfonii państwa i Kościoła zakładała głęboki szacunek dla Bożego prawa, jak również poszanowanie i przestrzeganie praw Kościoła. Trzysta lat później Justynian, będąc człowiekiem głęboko wierzącym, traktował już chrześcijaństwo jako dziedzinę ściśle związaną z państwem, czego symbolem był słynny orzeł bizantyński - jedno ciało, lecz dwie różne orientacje ideologiczne, czyli Kościół o wymiarze eschatologicznym i cesarstwo skupione 
na ziemskim wymiarze swego posłannictwa. Jeśli jednak dochodziło do momentów ingerowania cesarzy w sprawy Kościoła, to fakt ten nigdy w Cesarstwie Wschodniorzymskim nie stał się zasadą. Wręcz przeciwnie, wysławiano licznych herosów wiary właśnie dlatego, że przeciwstawiali się heretyckim cesarzom, śpiewano w kościołach hymny na chwałę św. Bazylego Wielkiego za jego kategoryczny sprzeciw wobec ariańskiego cesarza Walensa, wychwalano św. Maksyma Wyznawcę za jego nieprzejednaną postawę wobec heretyckiego cesarza Konstansa i pisano laudacje mnichom męczennikom za ich świadectwo wiary wobec cesarzy ikonoklastów.

Okres panowania Justyniana (527-565) był jednocześnie schyłkiem funkcjonowania starożytnych wierzeń pogańskich, zamknięcie zaś ostatniej pogańskiej akademii w Konstantynopolu było symbolem tego, że stara religia została definitywnie wygnana z Bizancjum. Justynian był ostatnim władcą chrześcijańskim głęboko przekonanym o boskim pochodzeniu władzy cesarskiej;

Z woli Boga - pisał on w swoich Nowelach - władamy cesarstwem, które przeszło na nas od Jego Boskiego Majestatu. Tylko Bóg i cesarz, który jest pierwszym po Bogu, mogą rządzić sprawiedliwie, cesarz bowiem powinien naśladować Boga w miłosierdziu okazując łaskawość, przez którą jedynie urzeczywistnia się naśladowanie Boga (Runciman 1982: 48).

Pisał o kapłanie i cesarzu jako dwóch wielkich błogosławieństwach, które spłynęły na ludzkość z tego samego boskiego źrodła. Tak jak Bóg stanowi ostateczne źródło prawa wiecznego, tak cesarz wybrany przez Boga jest ostatecznym źrodłem prawa ziemskiego (Doroszkiewicz 2012: 162).

Jeśli współczesna historiografia krytykuje panowanie Justyniana, nazywając ten okres czasem podporządkowania Kościoła cesarzowi, to nie jest to do końca prawda, ponieważ istniała nieprzekraczalna różnica pomiędzy cesarstwem a uświęcającą i zbawczą rolą Kościoła. Poza tym cesarz był uzależniony od prawa boskiego, obowiązującej doktryny dogmatycznej i powinności filantropii, które nakładał na niego chrześcijański charakter jego urzędu. Po tragicznych wydarzeniach związanych z ikonoklazmem, nastąpił okres ponownej rewizji relacji pomiędzy Kościołem a państwem. Największym głosicielem idei nieingerowania państwa w sprawy kościelne był św. Teodor Studyta, który stał na stanowisku, że cesarz nie tylko nie powinien narzucać Kościołowi doktryny, jak to czynili 
cesarze ikonoklaści, ale w ogóle nie powinien sprawować władzy nad Kościołem. Uważał, że to cesarz, jak każdy inny laik, musi się podporządkować prawom Kościoła i nie może być zwolniony z obowiązku stosowania się do nich z tytułu swego stanowiska (Runciman 1982: 119).

Albo cesarz jest Bogiem - pisze on - albowiem jedynie boskość nie podlega prawu, albo panuje anarchia i rewolucja. Albowiem jakże może panować pokój, jeśli nie ma prawa obowiązującego wszystkich, jeśli cesarz może spełniać swe pragnienia, np. cudzołożąc lub uznając herezje, podczas gdy jego poddanym zakazane jest nawet porozumiewanie się z cudzołożnikami lub heretykami (Meyendorff 1989: 74).

Analizując powyższy tekst, wybitny bizantolog ks. John Meyendorff, dodaje, że:

Teodor nie był z pewnością nowatorem w swej postawie wobec państwa. Jego postawa była bowiem postawą Atanazego z Aleksandrii, Jana Chryzostoma, Maksyma Wyznawcy, Jana z Damaszku. Zajmuje ją rownież spora część duchowieństwa bizantyńskiego w późniejszych stuleciach. Postawa ta jedynie ilustruje fakt, że społeczeństwo bizantyńskie było dalekie od znalezienia tej «harmonii» między dwoma władzami, o której Justynian mówił w swojej szóstej Noweli (Meyendorff 1984: 74).

Sto lat poźniej cesarz Bazyli I w swej Epanagoge przedstawia Kościół i państwo jako jedną instytucję złożoną z wielu członków i części, na której czele stoją obok siebie cesarz i patriarcha, dwaj zwierzchnicy chrześcijańskiego świata, współpracują ściśle dla dobra ludzkości (Ostrogorski 1967: 210). Podczas ponowania dynastii macedońskiej, jeśli cesarz mógł pośrednio wpływać na wybór patriarchy lub ważnego dostojnika kościelnego, nie miał żadnego prawa anulowania lub zmieniania uchwał najwyższej instancji w Kościele, którą jest sobór powszechny albo ważny synod kościelny. Wobec tego, jak stwierdza Georgije Ostrogorski, Kościół w Bizancjum był jedyną instytucją, która wymykała się spod absolutyzmu cesarza, którego obowiązkiem było jedynie roztaczanie opieki nad Kościołem (Ostrogorski 1967: 214). Od okresu postikonoklazmu aż do momentu ostatecznego upadku Konstantynopola w 1453 roku, w obliczu nadciągającej katastrofy ze strony islamu, jakiekolwiek nadużycia ze strony władzy cesarskiej względem Kościoła należały do rzadkości. Po ostatecznym upadku Cesarstwa Wschodniorzymskiego ziemskie imperium przestało istnieć, natomiast Kościół, w myśl słów Chrystusa „zbuduję Kościół mój, a bramy piekielne go nie przemogą", żyje nadal. 
Do dziś w zasadzie nie pojawiło się jeszcze naukowe opracowanie genezy i ewolucji bizantyjskiej monarchii. Kościół chrześcijański po 300 latach strasznych prześladowań, wychodząc z podziemia, musiał się odnaleźć w nowej rzeczywistości, powziąć pewne decyzje: czy wyciągnąć rękę do pojednania i współpracy, czy odizolować się od upadłego świata, jak to czyniły liczne sekty, i zbawiać wybranych? Kościół zaryzykował, wybierając pierwszą możliwość, wziął na siebie odpowiedzialność za zbawienie upadłego świata. W nowej rzeczywistości to właśnie cesarz, wczorajszy prześladowca Kościoła, musiał przekonać chrześcijan, że jest nie tylko ich przyjacielem, ale i dobroczyńcą. Obok chrystianizującego się cesarstwa pojawiła się więc nowa władza, reprezentująca Kościół o charakterze eschatologicznym. Historia Cesarstwa Wschodniorzymskiego jest również historią relacji pomiędzy Kościołem niosącym zbawienie grzesznikom i cesarstwem skupionym na ziemskim wymiarze swego posłannictwa. Symbolem tych relacji był słynny orzeł bizantyński - jedno ciało, lecz dwie różne orientacje ideologiczne. Wprawdzie relacje te nie zawsze były idealne, niemniej oba ciała funkcjonowały przez okres 1100 lat na zasadzie symfonii. Po upadku Cesarstwa Wschodniorzymskiego to Kościół, z woli Bożej, przeżył, aby kontynuować swą misję zbawiania upadłego świata.

\section{Literatura}

Batiffol P., 1929, La paix constantinienne et catholicisme, Paris.

Bober A., 1965, Światta ekumeny. Antologia patrystyczna, Kraków.

Doroszkiewicz W., 2012, Dzieje wschodnich Rzymian, Białystok.

Mazzarino S., 1966, The End of the Ancient World, London.

Meyendorff J., 1984, Teologia bizantyjska, przeł. J. Prokopiuk, Warszawa.

Meyendorff J., 1989, Imperial Unity and Christian Divisions, New York.

Ostrogorski, G., 1967, Dzieje Bizancjum, przekł. pod red. H. Evert-Kappesowej, Warszawa.

Runciman S., 1982, Teokracja bizantyjska, przeł. M. Radożycka-Padetti, Warszawa.

Schmemann A., 1979, Church World Mission, New York.

Schwartz E., 1913, Kaiser Constantin und die christliche Kirche, t. 1, Leipzig-Berlin.

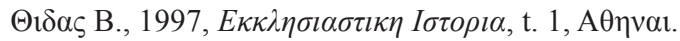

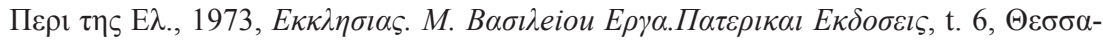

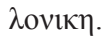

